\title{
Value Proposition Design for Custom Clothing Startup Using Design Thinking Approach
}

\author{
Astri Ghina ${ }^{1}$, Nurul Afifah ${ }^{2}$ \\ Master of Management, Faculty of Economics and Business, Telkom University, Bandung, Indonesia
}

\begin{abstract}
There are thousands of digital-based startups in Indonesia, but only a few have sustainable business development. One of the reasons is the products created by startups are not under market needs. Fashion is one of the potential startups to develop in the digital age because it is the second-largest subsector that contributes to the Indonesian economy. In fashion, especially in customized clothing, business participants' main obstacle is low competitiveness against those who own a branded business. This situation is indicated by dissatisfaction with the quality of the service, which resulted in unfaithful users. This research aims to explore the interaction between custom clothing businesses and their users so that the concerns coming from both parties can be used as the basis for creating digital-based solutions. This research focused on exploring the interaction between tailors and sewing service users using a design thinking approach. The qualitative method is used in this research, and information is gathered using a survey strategy. Data collection is conducted by in-depth interviews with tailors and sewing service users. Besides, observation is used to understand the tailor's daily activities. The result shows that there is a concern between tailors and their users. As a digital-based solution, the proposed idea is project management with a transparent sewing service process that sewing service users can see. This research is limited to formulating digital feature ideas that can be used as the basis for designing a rapid prototype. Validation of the prototype can be conducted in the next study.
\end{abstract}

Keywords - Value Proposition Design, Startup, Design Thinking, Custom Clothing, Tailor.

\begin{abstract}
Abstrak
Usaha rintisan berbasis digital di Indonesia mencapai ribuan unit, namun hanya sedikit yang usahanya dapat berkesinambungan. Salah satu penyebabnya bahwa produk yang diciptakan oleh pelaku usaha rintisan tidak sesuai dengan kebutuhan pasar. Salah satu usaha rintisan yang berpotensi untuk berkembang di era digital adalah fesyen karena menjadi subsektor terbesar kedua yang memberikan kontribusi bagi perekonomian di Indonesia. Kendala utama yang dialami oleh para pelaku usaha di bidang fesyen, terutama pakaian custom adalah daya saing yang rendah terhadap pelaku usaha yang sudah memiliki merek. Hal tersebut diindikasikan dengan ketidakpuasan akan kualitas layanan yang mengakibatkan pengguna menjadi tidak setia. Penelitian ini bertujuan untuk mengeksplorasi interaksi antara pelaku usaha pakaian custom dengan pengguna layanan sehingga keresahan dari kedua belah pihak dapat dijadikan dasar untuk menciptakan solusi berbasis digital. Fokus penelitian ini mengeksplorasi interaksi para penjahit dan pengguna jasa jahit dengan menggunakan pendekatan design thinking. Strategi survei digunakan untuk mengumpulkan informasi dengan menggunakan metodologi kualitatif. Teknik pengumpulan data yang digunakan adalah wawancara secara mendalam dengan para penjahit dan pengguna jasa jahit. Selain itu, teknik observasi digunakan untuk memahami aktivitas sehari-hari dari para penjahit. Temuan menunjukkan bahwa ada keresahan yang dialami oleh penjahit dan pengguna jasa jahit. Ide yang diusulkan sebagai solusi berbasis digital adalah berupa tahapan proses layanan jahit yang bersifat transparan dapat dilihat oleh pengguna jasa jahit. Penelitian ini dibatasi pada tahap merumuskan diagram alir dari proses tahapan menjahit yang dapat dijadikan dasar untuk merancang purwarupa. Validasi purwarupa tersebut dapat dilakukan pada penelitian selanjutnya.
\end{abstract}


Kata kunci- Desain Proposisi Nilai, Usaha Rintisan, Design Thinking, Pakaian Custom, Penjahit

\section{INTRODUCTION}

Academics and practitioners believe that the Covid-19 pandemic has accelerated the digitalization process in Indonesia. Pandemic has opened up many opportunities to create "smart" solutions in adopting new habits in everyday life. This situation provides many opportunities for digital startups to enter various sectors of the creative economy. The creative industry maintains excellent growth in Indonesia, especially the digital creative industry since it has grown significantly throughout the year. This situation should be a significant force to bring a tremendous economic impact to Indonesia in the future. The government has also made it clear to promote Indonesia as one of the countries with the most extensive digital industry strength, with Indonesia's vision to be The Digital Energy of Asia.

Based on Masyarakat Industri Kreatif Teknologi Informasi dan Komunikasi Indonesia, knowns as MIKTI, Indonesian Society of Creative Industries for Information and Communication Technology, the number of startups in Indonesia in 2018 was 992. Startup distribution in Indonesia is in Jabodetabek for 522 (52.62\%), Central Java for $30(3.02 \%)$, Yogyakarta for 54 (5.44\%), West Java for 44 (4.44\%), East Java for $113(11.39 \%)$, Bali \& NTB for $32(3.23 \%)$, Kalimantan for 24 (2.42\%), Sulawesi for 34 (3.43\%), Sumatra for $115(11.53 \%)$, and unknown residences for $24(2.42 \%)$. Many startups are certainly supported by the rapid use of the internet in Indonesia (MIKTI \& Teknopreneur Indonesia, 2018). According to APJII (Association of Indonesian Internet Service Providers), Internet users in Indonesia reached 196.7 million people (73.7\%) in the second quarter of 2020. This number increased by 25.5 million users compared to 2019 (Jatmiko, 2020).

The increasing trend of internet users in this pandemic era is one factor of the rapid flow of digitalization in various sectors in communication, transportation, trade, education, finance, and various other sectors in Indonesia. New habits adaptation has forced people to interact in different ways; online interaction has become necessary in carrying out daily activities. However, intense competition to dynamic community response is very influential on the sustainability of startups. Business continuity depends on its ability and speed to adapt to existing market conditions. Many startups failed to develop and eventually had to shut down because they could not adapt to this digital age's competitive conditions. The startups are currently reaching thousands of units, and only a few were survived.

Non-banking director, Syaifullah Agam, said that the startup's failure was caused by unskilled experts in management, technology, and financing issues (Anggono, 2019). The aspect of reaching the market is also essential because startups find and execute the solution to the problems that existed in the community, so market research must be done carefully (Movanita, 2019). Minister of Communication and Informatics (Menkominfo) of the Working Cabinet 2014-2019, Rudiantara, stated that establishing startup companies in Indonesia is still low on the international scale because most startups put more emphasis on technological intelligence. However, they forget about the market (Yadika, 2019). The startup's success rate in Indonesia is 5\%, and according to the Bureau of Labor Statistic (BLS) report, about $50 \%$ of startups failed in the first fourth years of establishing their business, $19 \%$ of startups failed due to intense competition and $18 \%$ failed due to cost issues (Merdeka, 2019).

Understanding obstacles faced by startups is also conducted by doing interviews with six founders of startups. This interview was conducted to find out the activities carried out by the startup. The survey was performed on three startups that have joined innovation laboratories and three independently-developed startups. The result shows that the startups face three obstacles. First, startups are still looking for customers and ensuring that they are suitable for the market. Second, independently-developed startups do not seem to know and understand the right methods in performing field validation to find a match between problem and solution. Third, the startups only have a small number of members, resulting in a lack of human resources to perform field validation.

Custom clothing is an example of a fashion subsector that has an excellent opportunity to be developed. This fact can be seen from the stable public information search trends in the last five years, 2016-2020 (Googletrends, 2020). However, this subsector faced many challenges in developing the business, one of which is the lack of competition for local products compared to imported products (BEKRAF, 2020). The low competitiveness is interconnected with the many obstacles experienced by custom clothing businesses, which are between the tailors and their customers. These barriers are explored by conducting interviews with the tailors and the customers who are often using the sewing services. The result shows issues experienced from the customer's side of custom clothing: difficulty to find tailors, clothing design is not as expected, and orders are not completed on time. The 
most common tailoring issues are punctuality, lack of human resources, and adaptation of clothing design. The problem's findings provide an overview of each party's needs and expectations to discover new ideas as an opportunity to find the solution.

It should be more comfortable for tailors to receive direct orders in this digital era because the information is very transparent nowadays. However, the sewing business is yet to have a particular platform, so they usually join online stores with various product and service categories. This situation provides an opportunity to create a particular platform that can connect orders directly to sewing businesses. One of the startups that already have the idea is Express Your Looks (eYours), a startup engaged in custom clothing. eYours acts as a platform that connects tailors and customers interested in custom clothing. eYours can be accessed through the website, but the service is currently closed due to many complex considerations to make it work. One of them is difficulties in communicating the complex order message from the customers to the tailors. This issue makes eYours stagnant to develop, and it is also a challenge to discover more about the main problems experienced by both customers and tailors. Exploration of this problem will be performed with a design thinking approach.

Design thinking is the proper approach to exploring the user's experience both from the customer's side and from the tailor's side. This approach can produce an in-depth picture of every concern and expectation of users who need an urgent solution. Based on the previous research, using design thinking can increase Business Intelligence's interest in providing appropriate dashboards between functions and users (Cahyadi \& Prananto, 2015). Further research shows that applying the design thinking method can help design successful social entrepreneurship projects by identifying the linkages between stakeholders and social entrepreneurship (Chou, 2018). Another research designed educational teaching methods using design thinking to solve problems in tourism studies. The draft results in encouragement of creativity, innovation, selective information, and collaboration given to the students (Sándorová, 2019).

Design thinking in this research is limited to identifying, solving problems, and developing ideas. eYours is a platform that brings customers and tailors together; it provides the two users to get the right solution ideas to answer the problems faced by both parties. The purpose of this research is to figure out and ensure the main problems between the customers and the tailors, so the result of this exploration can be used as a guide to finding a digital-based solution for custom clothing services. Research questions, research objectives, and methods to answer research questions to explore the custom clothing phenomenon can be seen in Table 1 .

Table 1. Research Questions, Research Objectives, and Methods

\begin{tabular}{clll}
\hline № & \multicolumn{1}{c}{ Research Questions } & Research Objectives & \multicolumn{1}{c}{$\begin{array}{c}\text { Methods To Answer Research } \\
\text { Questions }\end{array}$} \\
\hline 1 & $\begin{array}{l}\text { What are the main problems } \\
\text { experienced by customers who } \\
\text { use } \text { custom } \text { clothing services? }\end{array}$ & $\begin{array}{l}\text { To analyze the } \\
\text { problems of sewing } \\
\text { service users }\end{array}$ & $\begin{array}{l}\text { In-depth interviews and identifying } \\
\text { into empathy maps }\end{array}$ \\
\hline 2 & $\begin{array}{l}\text { What are the main problems } \\
\text { experienced by custom clothing } \\
\text { businesses (tailors) in serving } \\
\text { their customers? }\end{array}$ & $\begin{array}{l}\text { To analyze the } \\
\text { problems of tailors }\end{array}$ & $\begin{array}{l}\text { a. In-depth interviews and identifying } \\
\text { into empathy maps } \\
\text { b. Observation of service process } \\
\text { activities to make clothes in the } \\
\text { working place of tailor business }\end{array}$ \\
\hline 3 & $\begin{array}{l}\text { What can digital-based solutions } \\
\text { be offered by eYours in solving } \\
\text { problems in the field of custom } \\
\text { clothing services? }\end{array}$ & $\begin{array}{l}\text { To build the solutions } \\
\text { that can be offered }\end{array}$ & $\begin{array}{l}\text { Brainstorm ideas with the founding } \\
\text { team and validate them to experts }\end{array}$ \\
\hline
\end{tabular}

\section{LITERATURE REVIEW}

Design in various fields is not new concepts and practices (Cooper et al., 2010; Liedtka, 2015). Design's focus is slowly shifting from designing physical products to matters related to systems and organizations (Cassim, 2013). One of the books that introduce design value in management is "The Science of the Artificial," written by Herbert Simon in 1969 and was revised in 1996. The management's design thinking development center is in Silicon Valley, where the International Design Consultancy IDE and Stanford University are located (Gruber et al., 2015). Both institutions have the primary role as developers of the Design Thinking method's innovation. 
IDEO continues to advance and promote design thinking through articles and books for business audiences (Brown, 2008; Brown, 2009). It was from the IDEO that the term Design Thinking first appeared.

In 2005, the Co-founder of SAP, a German software company, David Kelley, and several colleagues established The Hasso Plattner Institute of Design (HPI) at Stanford. A second HPI Institute was established at the University of Potsdam, Germany, in 2007 (Plattner et al., 2011). Both institutions have contributed significantly to design thinking development by improving structured-course curriculum, seminar offerings, free teaching materials, and design thinking research (Huber, 2017). The University of Toronto has since adopted and further developed the design thinking method (Dunne \& Martin, 2006).

In many fields, the development of design impacts the continually changing definition according to the context. Some authors said that there is no universal definition of design thinking (Huber, 2017). Based on organizational context, design thinking has been implemented at various levels (Martin, 2013). In the thesis article written by Huber (2017), he found three types of managements' design thinking. The first type can be described as "IDEOs' way of working with design and innovation." IDEO played a significant role in design thinking's development. The second type is from the University of Toronto, which describes design thinking as an effective method of solving organizational problems. It proposes that this design thinking method is an essential skill in a manager's training. The third type was identified by Johansson-Sköldberg et al. in 2013, who stated design thinking as part of management theory.

Design thinking is about implementing tools and methods adapted from design practices (Cruickshank \& Evans, 2012). User's Ethnographic Research can be conducted to find potential users' latent needs (Brown, 2009). Personas can collect market data and find out the user stereotypes (Tonkinwise, 2011). User journey mapping can help understand the case of a product or service's usage at various time points (Liedtka, 2015). The invention of rapid prototypes can help to clarify the proposed solution (Brown, 2009). These tools can be implemented in figuring out the problem's approach from three different points of view. First, the innovator needs to find what solution is desired from the customer's point of view. Second, the innovator needs to propose a technologically feasible solution. Third, the innovator also needs to implement and measure the potential solution through an appropriate business model (Brown, 2009). Brown described the definition of design thinking on IDEO's website as "Design thinking is a human-centered innovation method. It draws inspiration from the designer's toolkit and integrates human needs, technical possibilities, and requirements for business success". (IDEO, 2016).

Besides, design thinking uses to develop the sustainable re-design concept of a startup; it is an effort to deal with market uncertainty to re-build value proposition (Antonopoulou \& Begkos, 2020). Value proposition design is considered a practice for digital startups/innovators to see the future conditions (Brem et al., 2019; Antonopoulou \& Begkos, 2020). The value proposition is an essential part of the overall value creation process that supports the customer experiences development (Äyväri et al., 2016; Lanning, 2003; Payne \& Frow, 2014; Sandstrom et al., 2008). The value proposition aims to match needs and jobs in achieving a suitable solution to a problem or product fit with market needs (Osterwalder et al., 2014). Therefore, startups must build a value proposition that describes an innovation model that is targeted, initiated, formulated, and implemented (Payne \& Frow, 2014). It has been recognized that this value proposition provides positive meanings to consumers, selfexpression, social values, and driving factors of consumer behavior (Yi et al., 2020).

The basis for developing innovation is consumer needs-centered in all business model elements (Ojasalo \& Ojasalo, 2018). Therefore, startups must realize the right time to interact with consumers (Shamim et al., 2017). Some organizations emphasize that value and value creation are understood as interactions and contextual shaped by social forces, norms, and a more comprehensive network of ecosystems (Äyväri \& Jyrämä, 2017). Understanding the value proposition in a business model makes it easy to map a business model related to the startup's running framework. Besides, value propositions are also used as a potential assessment for the focus of change (Kristensen \& Remmen, 2019).

Design thinking is an appropriate tool to develop innovation at startup since it is a human-centered or customercentered tool (Brown, 2009). The focus is to continuously discover potential customers' latent needs to increase the quality value proposition of its products and services (Wattanasupackoke, 2012). Design thinking as a holistic approach helps organizations drive innovation and growth (Liedtka \& Ogilvie, 2011). Design thinking is used to solve complex, ambiguous, and unclear problems (Glen et al., 2015). The iterative nature of the method offers an alternative way to develop a solution (Brown, 2009) that would not work with management theories' analytical approach (Collins, 2013). Management theory focuses on stable and predictable aspects where recommendations are drawn from past incidents (Martin, 2009), while the design thinking concept uses abductive logic focusing on the question "what might happen?" (Collins, 2013). 
Design thinking literature is dominated by numerous practical and pragmatic methods to support design thinkers in different and convergent design processes (Brown, 2008). Many leading companies have implemented design thinking to achieve various goals in their organizations. In the previous research, Glen et al. (2015) showed a change in passive teaching into more active problem-based learning. The design thinking approach is only used in design learning methods to improve the previous learning methods. Meanwhile, Nielsen et al. (2015) only used the design thinking approach to ensure curriculum design to bridge the present and future. The design thinking approach is also used to compare learning experiences in design learning by providing more critical framework guidance for effective designs and facilities (Mosely, 2018).

The design thinking approach is used to drive cultural transformation in creating a better outcome for internal and external stakeholders, such as Hewlett-Packard, Deloitte, and PepsiCo (Sato et al., 2010; Howard, 2012; Nooyi \& Ignatius, 2015). The design thinking approach is also used to create and test new products in the health field (Brown, 2008; Carlgren et al., 2014). At Bank of America, design thinking is used to develop the customer's experience in savings (Brown, 2008) and bank services to be more accessible (Carlgren et al., 2016). In the public sector, design thinking is also used to provide adequate public services based on the user community's needs (Gruber et al., 2015).

In the field of social innovation and entrepreneurship, design thinking has been used by Bill \& Melinda Gates Foundation to understand the women's needs in developing countries so initiatives actions can be carried out for the sake of their future (Gates, 2015). Chou (2018) stated that the design thinking approach is used to find the connection of social entrepreneur attributes in providing illustrations to support new methodologies in designing social entrepreneurship projects.

The 3M company used a design thinking approach to build a meaningful solution that meets users' expectations (Porcini, 2009). Proctor \& Gamble used design thinking to customize their products to align with the user's needs. In Panasonic, design thinking principles are included in their new product development practices (Carlgren et al., 2016). IBM used design thinking to train its sales staff to focus more on clients (Kolko, 2015).

Design thinking applied in the research of information study focuses on user's journey with immersion phase, ideation phase, and implementation phase. The research shows that the design thinking approach can increase user experience and contribute to engaging the people to create innovation for information-related problems (Nakano, 2018). General Electric used a design thinking approach to shift business focus to software providers (Kolko, 2015). AT SAP, a German multinational software company used a design thinking approach to help the SAP team develop a rapid prototype to better communicate product ideas to the market (Holloway, 2009).

Design thinking methods in many fields impact management theory and practice; even some researchers described design thinking as the best way to be creative and innovative in the managerial field. Some researchers argued that design thinking in research needs to be further developed (Huber, 2017). Based on previous literature, design thinking is mostly applied in an established large-scaled organization of education, cultural transformation, health, finance, public services, technology and information, consumer goods, and social innovation and entrepreneurship. Few works of literature discussed using design thinking methods to test ideas proposed by a startup to meet its users' needs. This research focuses on using design thinking methods in a startup to understand the custom clothing users to find suitable ideas and propose solutions for existing problems.

\section{RESEARCH Methodology}

This research starts with the preliminary data collection to understand the phenomenon for better understanding. This preliminary data is analyzed to determine the objective of the research. Next, a literature study is carried out to find gaps and determine the position of the research. A conceptual framework is formed based on related theories and previous research. The framework is created in the form of diagrams to map research flows.

The inductive approach is applied in the development of theory; this approach starts with a general topic and some unclear ideas, which will be corrected and elaborated into more precise concepts (Neuman, 2014: 70). This research was conducted because there is no ideal condition of startups in custom clothing services. Therefore it is necessary to trace the facts in the field along with the process of data collection.

The strategy used in this study is a survey. The survey gathers people's information to describe, compare, or explain knowledge, attitudes, and behaviors (Fink, 2003). The survey is commonly used in exploration and descriptive research. This research's context is surveys conducted on the subjects of decision-making, customer 
satisfaction, use of services, and the likes (Sekaran \& Bougie, 2016: 97). The survey is used because it investigates and collects data related to knowledge, attitudes, and behaviors in depth from tailors and their customers.

Qualitative is used as the research's method. This method is used to understand and identify patterns of behavior owned by users and assist in designing projects (Cooper, 2007: 50). This study identifies tailor and customer's issues and understands the situation experienced in custom clothing service activities.

The unit analysis of this research is carried out on individuals. The purposive sampling method is used in this research, where researchers can decide which informants represent the phenomena being studied. There are three types of informants, namely users of sewing services, tailors, and experts.

Data collection techniques used in this study are in-depth interviews and observations. Data collection steps include selecting informants, gathering information through interviews and unstructured or semi-structured observations, documents, and visual materials (Creswell \& Creswell, 2018: 250).

The interview was conducted in two stages; the first stage was conducted to find out the feelings, thoughts, and behaviors of the custom clothing services. In the second stage, the interview was conducted to validate the proposed idea, a digital-based solution. In this phase, interviews are conducted to find out whether the proposed features are necessary. The experts of custom services conduct this validation. List informants can be seen in Table 2.

Table 2. Research's Informants

\begin{tabular}{llccc}
\hline \multicolumn{1}{c}{ Sources } & \multicolumn{1}{c}{ Criteria } & $\begin{array}{c}\text { Number } \\
\text { (Person) }\end{array}$ & $\begin{array}{c}\text { Stages } \\
\text { Inspiration }\end{array}$ & $\begin{array}{c}\text { Types of Data } \\
\text { Collection }\end{array}$ \\
\hline Tailor & $\begin{array}{l}\text { They have been in the sewing } \\
\text { business for at least one year }\end{array}$ & 6 & Inspiration & Interview \\
\hline $\begin{array}{l}\text { Customers who use } \\
\text { sewing services }\end{array}$ & Women & 6 & Ideation & Interview \\
\hline Expert & Frequent use of sewing services & & & \\
& $\begin{array}{l}\text { Sewing service has been } \\
\text { established for at least three } \\
\text { years } \\
\text { Familiar with online services for } \\
\text { at least one year }\end{array}$ & & & \\
\hline
\end{tabular}

Observations were performed by doing a field study and taking notes, figuring out individual behaviors and activities on the research site. The observation stage is only conducted on tailors because, in this phenomenon, tailors as service providers received many complaints from customers about their services. Therefore, it is necessary to directly observe daily activities in processing orders at the sewing place. The Observation was conducted on six tailors in one visit for more than 4 hours long. Observation focuses on sewing services stages from fabric delivery, fashion design, body measurement, patterns \& cutting, sewing, fittings, adjustment, and clothing delivery.

The characteristics of observations are uncontrollable due to the absence of prior arrangements. It is nonparticipant observations because the researchers were not seen in the speakers' daily lives. The observations were carried out in a structured manner because researchers have determined what aspects should be obtained in these observations. This Observation is non-secret because the tailors are aware of being the object of research. (Sekaran \& Bougie, 2016).

Collected data from interviews and observations are grouped into empathy maps to articulate customers' and tailors' needs. This stage is preceded by data reduction of the interview's result. Then, collected data is grouped into an empathy map based on "Think" (user's thoughts and ideas), "Feel” (understanding of user's feelings), "Do "(represent what the user does and how they behave), "Pain "(anxiety experienced by the user), and "Gain" (user's desires) (Ferreira et al., 2015). 
The findings of customers' problems from the interview results were analyzed using a 5-scale negative and positive range. This scale is used to strengthen the processed result of customer and tailor's experience. The results of the analysis are presented in the form of graphs. An explanation of each scale value can be seen in Table 3.

Table 3. Description of 5-Scales Positive and Negative Ranges

\begin{tabular}{cll}
\hline Scale & \multicolumn{1}{c}{ Description } & \multicolumn{1}{c}{ Explanation } \\
\hline 5 & Very Strong Positive & Positive view with a very strong driving factor \\
\hline 4 & Strong Positives & Positive view with strong driving factors \\
\hline 3 & Positive & Positive view \\
\hline 2 & Weak Positive & Positive view, but with a weak driving factor \\
\hline 1 & Very Weak Positive & Positive view, but with a fragile driving factor \\
\hline 0 & Neutral & Neutral \\
\hline-1 & Very Weak Negative & Negative views, but with a fragile driving factor \\
\hline-3 & Weak Negative & Negative views, but with a weak driving factor \\
\hline-4 & Strong Negative & Negative views \\
\hline-5 & Very Strong Negative & Negative view with a very strong driving factor \\
\hline
\end{tabular}

After figuring out the problems and opportunities of the empathy map results, we proceed to enter the ideation stage, carried out by performing discussion with the founding team to develop solution ideas. After formulating the idea as a solution, validation is conducted by a short interview with the experts. This stage is performed to ensure that the proposed idea is essential. The final result of this research is the formulation of a solution concept for custom clothing startups as a guide to making prototypes.

The research results are presented and discussed to answer research questions, namely about the main problems experienced by customers and tailors and solutions to overcome the issues. The last stage is to conclude the findings and state the limitations of this research to open the opportunity to conduct another research in the future. An illustration of the research stage can be seen in Figure 1. 


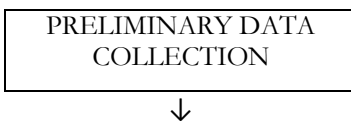

RESEARCH PURPOSES
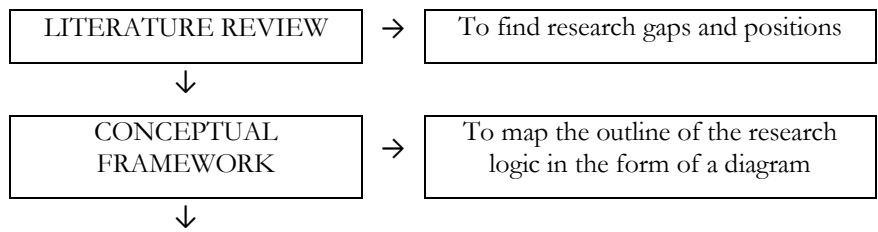

Adopted by: IDEO by Tim Brown \& Jocelyn Wyatt

RESEARCH METHODOLOGY

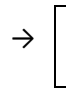

To determine the appropriate methodology for research

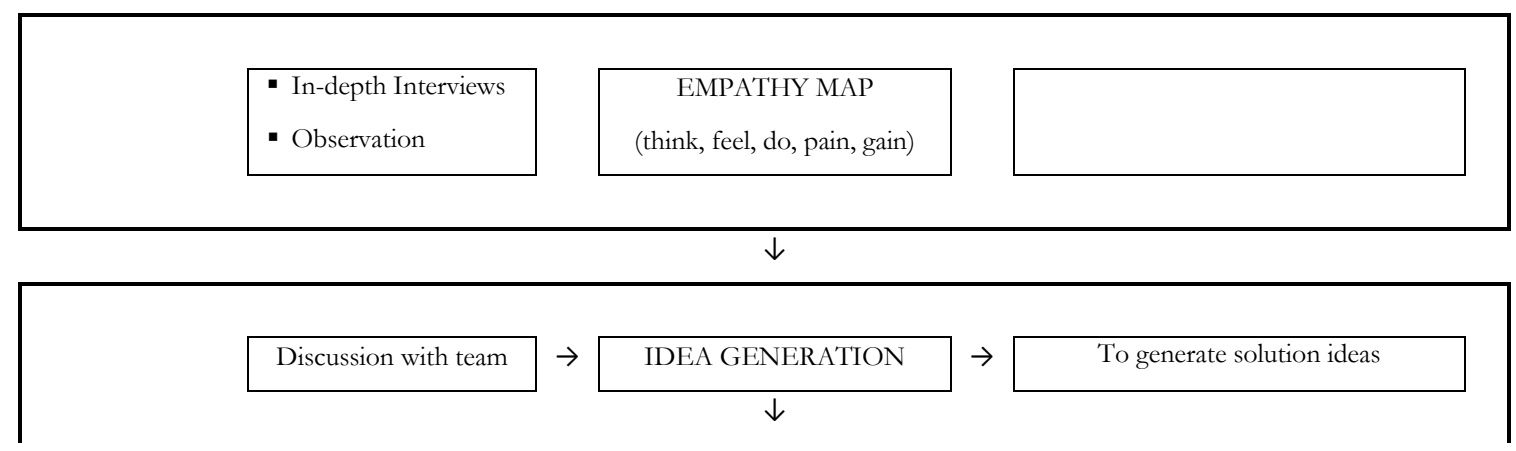




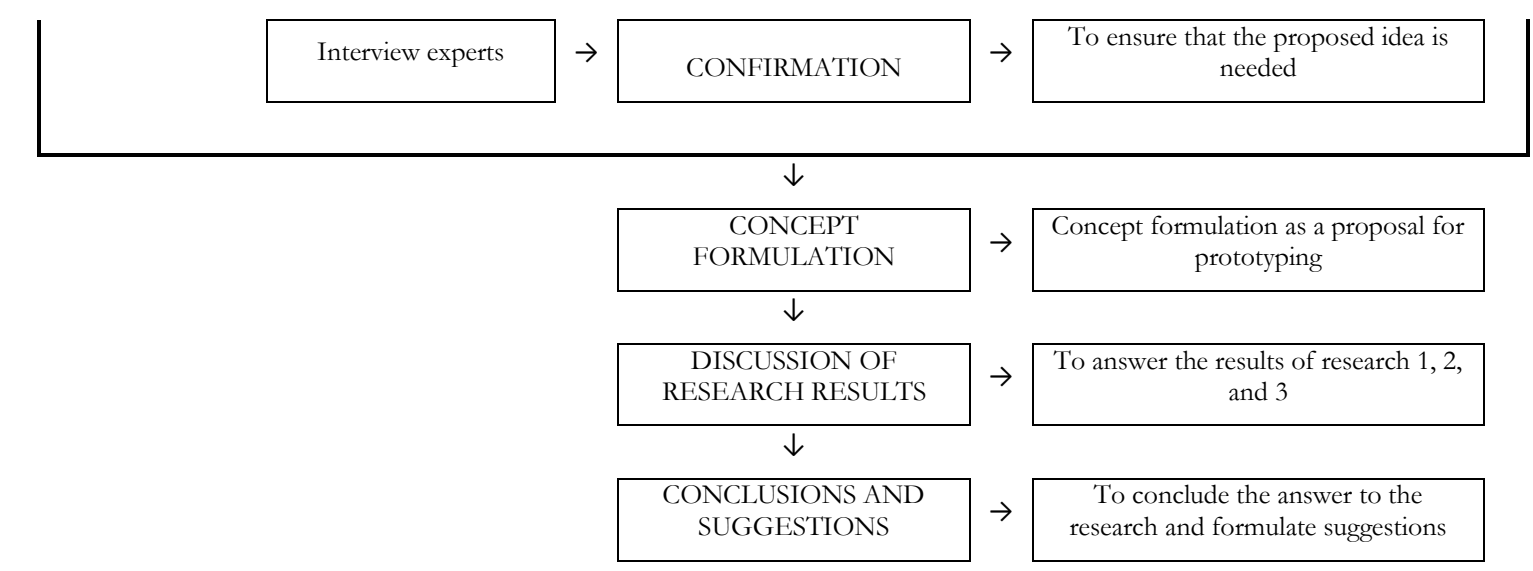

Figure 1. Research Methods

\section{Validity and Reliability}

Research validation is performed to examine the accuracy and credibility of the findings using specific procedures. Qualitative validity checks if the findings are accurate from the researchers, participants, or readers' perspective. Qualitative reliability shows that the researchers' approach is consistent (Creswell \& Creswell, 2018: 264). The validity of this study can be seen in Table 4 (Yin, 2014).

Table 4. Validity and Reliability of Research

\begin{tabular}{llll}
\hline \multicolumn{1}{c}{ Testing } & \multicolumn{1}{c}{ Description } & \multicolumn{1}{c}{ Tactics } & Research Phase \\
\hline $\begin{array}{l}\text { Validity } \\
\text { Construction }\end{array}$ & $\begin{array}{l}\text { To check how well the results obtained } \\
\text { from the use of measuring instruments }\end{array}$ & $\begin{array}{l}\text { Use data triangulation to } \\
\text { build justifications }\end{array}$ & Data collection \\
\hline $\begin{array}{l}\text { Internal } \\
\text { Validity }\end{array}$ & $\begin{array}{l}\text { Ensuring the research has been } \\
\text { conducted analysis logically as presented } \\
\text { and reconstructed by researchers }\end{array}$ & $\begin{array}{l}\text { Use a narrative case } \\
\text { explanation. }\end{array}$ & Data analysis \\
\hline Reliability & To check the reliability of the research. & $\begin{array}{l}\text { Use the interview } \\
\text { protocol }\end{array}$ & Data collection \\
\hline
\end{tabular}

\section{RESUlTS AND DisCUSSION}

\section{A. Inspiration Stage}

In this stage, observations were performed to see people's experiences to identify the issues or opportunities that drive us to find the solution (Brown \& Wyatt, 2010). The inspiration stage becomes an essential part of the design thinking process, the foundation for ideation. The inspiration stage is about how to frame problems, collect meaningful data, and interpret data. In this phase, Inspiration is divided into two parts, based on the user's experience of sewing services (customers) and tailors.

\section{Empathy Map Consumers}

The mapping results were gained from interviews with six customers; then, the reduced data was grouped on an empathy map. The results for each consumer's empathy map are summarized based on the customers' most experienced things. The summary of the customer's empathy map can be seen in Table 5.

Table 5. Summary of Customer's Empathy Map 


\begin{tabular}{|c|c|}
\hline \multicolumn{2}{|c|}{ Customer's Empathy Map } \\
\hline THINK & FEEL \\
\hline $\begin{array}{l}\text { a. They were afraid that the tailor did not } \\
\text { understand the piece of information. }\end{array}$ & $\begin{array}{l}\text { a. They were worried that fashion design does } \\
\text { not match the expectation. }\end{array}$ \\
\hline $\begin{array}{l}\text { b. They think that some tailors did not } \\
\text { complete the order on time. }\end{array}$ & $\begin{array}{l}\text { b. They were worried about the clothing size } \\
\text { does not fit properly. }\end{array}$ \\
\hline $\begin{array}{l}\text { c. They think the tailor provides fashion } \\
\text { fitting time close to the promised day. }\end{array}$ & $\begin{array}{l}\text { c. They were worried about not getting specific } \\
\text { information from the tailor. }\end{array}$ \\
\hline \multicolumn{2}{|r|}{ DO } \\
\hline \multicolumn{2}{|c|}{$\begin{array}{l}\text { a. They usually meet in person with the tailor; they were communicating online to explain the } \\
\text { fashion design. }\end{array}$} \\
\hline \multicolumn{2}{|c|}{ b. They usually try to remind the tailor about the order; they ask for an updated sewing process. } \\
\hline \multicolumn{2}{|c|}{ c. They usually come to the tailor for fashion fitting time. } \\
\hline PAIN & GAIN \\
\hline $\begin{array}{l}\text { a. They were fretful from his experience that } \\
\text { tailors are often forgetful and late. }\end{array}$ & a. They hope the order will finish on time. \\
\hline $\begin{array}{l}\text { b. They were fretful clothes do not fit on the } \\
\text { body, or some part needs to be fixed. }\end{array}$ & $\begin{array}{l}\text { b. They hope the order quality meets } \\
\text { expectation. }\end{array}$ \\
\hline $\begin{array}{l}\text { c. They were fretful not getting specific } \\
\text { information from the order progress. }\end{array}$ & $\begin{array}{l}\text { c. They hope to get updated information from } \\
\text { tailors about the order progress. }\end{array}$ \\
\hline
\end{tabular}

After analyzing with 5-scales range, graphs of the customer's appraisal summary can be seen in Figure 2.

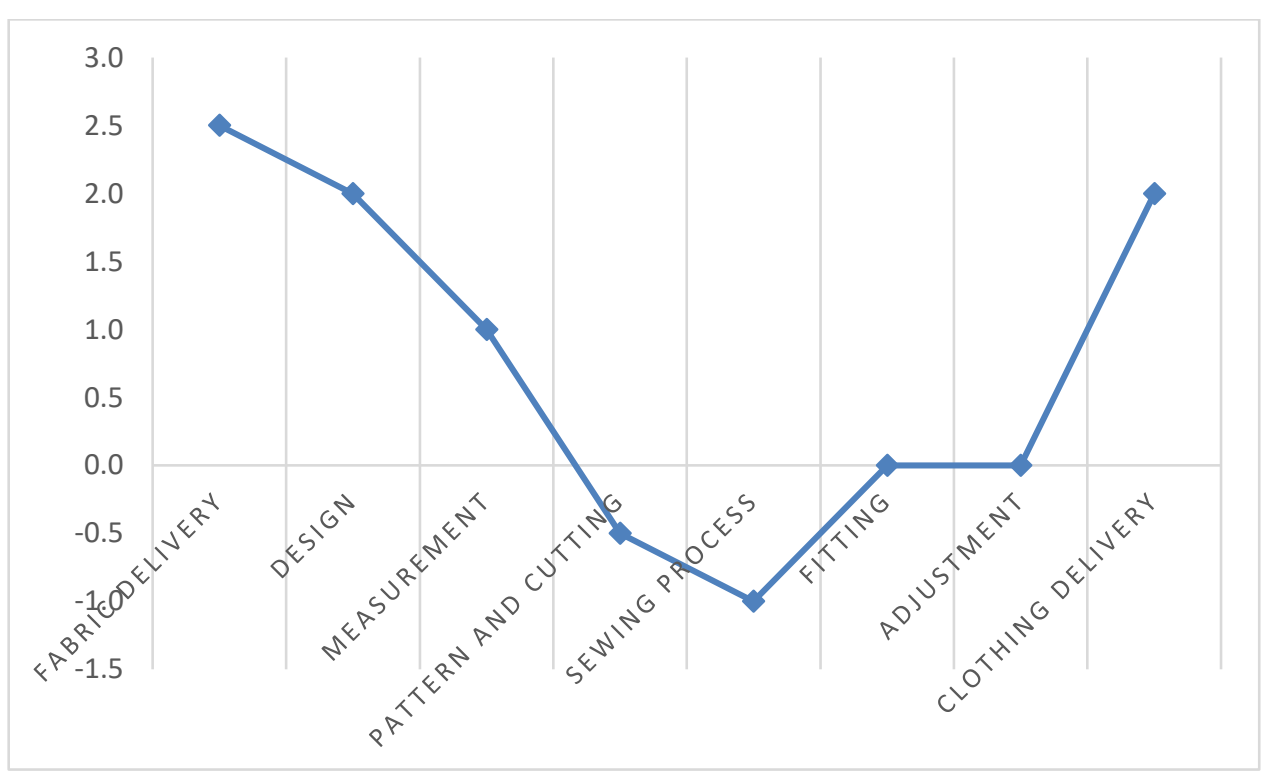

Figure 2. Customers Appraisal Summary Graphic 
The result shows negative experiences in several stages of sewing. This negative appraisal is a problem faced by consumers and is the basis for developing ideas as a solution. The summary of problems from consumers can be seen in Table 6 .

Table 6. Summary of Negative Ratings from Customers

\begin{tabular}{|c|c|c|}
\hline Consumer & Sewing Service Stage & Problems \\
\hline & Fashion Design & $\begin{array}{l}\text { She had a difficult time communicating expectation } \\
\text { when equalizing the perception. }\end{array}$ \\
\hline & Pattern \& Cutting & The clothing size smaller than the expectation. \\
\hline & Fittings & $\begin{array}{l}\text { The order completion close to the promised day; she } \\
\text { did not do the fashion fitting time. }\end{array}$ \\
\hline & Adjustment & $\begin{array}{l}\text { The clothing adjustment was ineffective; she had to go } \\
\text { back many times. }\end{array}$ \\
\hline & Measurement & $\begin{array}{l}\text { The tailor's note was missing; the consumer had to re- } \\
\text { measured the body-size. }\end{array}$ \\
\hline & Sewing & The order completion was over the promised-day. \\
\hline & Pattern \& Cutting & The sewing result was not as her expectation. \\
\hline & Sewing & The order completion was over the promised-day. \\
\hline & Fittings & The order close to the promised-day. \\
\hline & Adjustment & The sewing result was unsatisfactory. \\
\hline Consumer 4 & Pattern \& Cutting & The clothing size smaller than the expectation. \\
\hline Consumer 5 & Sewing & $\begin{array}{l}\text { The tailor was late to execute the order; the tailor } \\
\text { forgot which fabric belongs to her. }\end{array}$ \\
\hline Consumer 6 & Fittings & $\begin{array}{l}\text { The tailor send information of fashion fitting time } \\
\text { close to the promised-day. }\end{array}$ \\
\hline
\end{tabular}

Based on Table 6, the sewing service stage issues are fashion design, measurement, patterns \& cutting, sewing, fittings, and adjustments. The finding shows that the tailor understands the proposed clothing design, but the outcome is not expected. This situation happens because of communication constraints between consumers and tailors, so the outcome is not fit with expectations.

The consumer had to return because the tailor lost the measuring data. Moreover, the customer's experience shows that the outcome was different from the designs or size was wrong. Another negative experience, customer's order were late, not as promised. Furthermore, fitting was requested too close to the promised day, so the measuring $\&$ adjustment were ineffective.

These conditions indicate customer's unfulfilled satisfaction. According to Kotler \& Armstrong (2001), customers will experience various satisfaction levels when the product is as expected. The factor that drives the customer's satisfaction is the quality of products and services. It is concluded that the tailor experienced some issues regarding product quality and services, which caused the customer's dissatisfaction.

\section{Empathy Map Tailor}

The mapping results are gained from interviews with six tailors; the reduced data are grouped on the empathy map. Results of the empathy map for each tailor are summarized of the tailor's experiences. The empathy map summary can be seen in Table 7 . 
Table 7. Summary of Tailor's Empathy Map

\begin{tabular}{|c|c|}
\hline \multicolumn{2}{|c|}{ Tailor's Empathy Map } \\
\hline THINK & FEEL \\
\hline $\begin{array}{l}\text { a. They need to equalize the perception with } \\
\text { consumers to note their needs. }\end{array}$ & $\begin{array}{l}\text { a. They were worried that the fashion } \\
\text { design or clothing size do not match with } \\
\text { customer's expectations. }\end{array}$ \\
\hline $\begin{array}{l}\text { b. They think to divide the working schedule } \\
\text { according to the priority date. }\end{array}$ & $\begin{array}{l}\text { b. They were fretful when unable to meet } \\
\text { the promised-day. }\end{array}$ \\
\hline $\begin{array}{l}\text { c. They think to send information to } \\
\text { customers. }\end{array}$ & $\begin{array}{l}\text { c. They feel disturbed when customers } \\
\text { always asking about the order progress. }\end{array}$ \\
\hline \multicolumn{2}{|c|}{ DO } \\
\hline \multicolumn{2}{|c|}{ a. They usually discuss with consumers to note their needs manually on a piece of paper. } \\
\hline \multicolumn{2}{|c|}{$\begin{array}{l}\text { b. They usually measure the consumer's body at working place; note the data manually on a } \\
\text { piece of paper. }\end{array}$} \\
\hline \multicolumn{2}{|c|}{ c. They were designing, studying patterns, and cutting fabrics. } \\
\hline \multicolumn{2}{|c|}{$\begin{array}{l}\text { d. They usually inform consumers about fashion fitting time; sometimes close to the promised- } \\
\text { day. }\end{array}$} \\
\hline \multicolumn{2}{|c|}{$\begin{array}{l}\text { e. They send clothes to consumers through delivery services; sometimes the clothes are picked } \\
\text { up by customers. }\end{array}$} \\
\hline PAIN & GAIN \\
\hline $\begin{array}{l}\text { a. They feel guilty when fashion design or } \\
\text { size do not match with customer's } \\
\text { expectation. }\end{array}$ & $\begin{array}{l}\text { a. They hope capable meet consumer's } \\
\text { expectations. }\end{array}$ \\
\hline $\begin{array}{l}\text { b. They often finish the order over the } \\
\text { promised-day. }\end{array}$ & $\begin{array}{l}\text { b. They hope to finish the order on time } \\
\text { without any adjustment. }\end{array}$ \\
\hline $\begin{array}{l}\text { c. They find some obstacles when had to } \\
\text { respond to all customer's messages. }\end{array}$ & $\begin{array}{l}\text { c. They hope capable send order progress } \\
\text { information without disturbing the } \\
\text { working process. }\end{array}$ \\
\hline
\end{tabular}

Observation is carried out to understand the tailor's experiences interacting with the customers and the sewing process. Findings from the Observation can be seen in Table 8.

Tabel 8. Findings from The Tailor's Observations

\begin{tabular}{cll}
\hline \multicolumn{1}{c}{ Tailor } & \multicolumn{1}{c}{ The Findings } & \multicolumn{1}{c}{ Problems } \\
\hline Tailor 1 & There was a stack of untidied fabric. & Arrangement of goods \\
\hline & $\begin{array}{l}\text { Measurement \& size charts are scattered and mixed with } \\
\text { other stuff. }\end{array}$ & Record documentation \\
\cline { 2 - 3 } & Stack of fabrics in a plastic bag. & Arrangement of goods \\
\hline & Messed up measurement chart. & Record documentation \\
\hline
\end{tabular}




\begin{tabular}{|c|c|c|}
\hline & $\begin{array}{l}\text { Employees looking for measures when they are about to } \\
\text { do patterns \& cutting. }\end{array}$ & Record documentation \\
\hline & $\begin{array}{l}\text { Design and measurement charts mixed with customer's } \\
\text { fabrics in a plastic bag, which stacked with other plastic } \\
\text { bags. }\end{array}$ & Record documentation \\
\hline & Scattered and missing pattern notes. & Arrangement of goods \\
\hline & $\begin{array}{l}\text { Confused employee searching stuff through piled-up } \\
\text { fabrics. }\end{array}$ & Arrangement of goods \\
\hline & $\begin{array}{l}\text { Angry customer on the fitting session due to a design } \\
\text { misunderstanding with the vendor. }\end{array}$ & Lack of communication \\
\hline Tailor 5 & Stack of fabric in a plastic bag used as a headrest. & $\begin{array}{l}\text { Ethics in maintaining } \\
\text { consumer goods }\end{array}$ \\
\hline Tailor 6 & $\begin{array}{l}\text { The customer called asking for the fabrics send back to } \\
\text { her, but the vehicle was overload, so the employee had to } \\
\text { go back to bring another vehicle. }\end{array}$ & Incomplete information \\
\hline
\end{tabular}

Tailoring's common problem is items' arrangement, such as rolls of cloth or piles of cloth in the plastic bags. This condition makes it difficult for the tailor to operate because the fabrics are scattered. Besides, an attitude may not look ethical because tailors used the customer's property as a cushion to lean on when they were sitting.

Another issue, notes were disorganized, which made it difficult for the tailors to find the customer's measurements. Moreover, ineffective and unclear communication between tailors and customers caused some misunderstanding; the tailor had to come twice to pick up the materials. This situation is connected to the tailor's work arrangements; things were not well organized, so the service was ineffective and inefficient. Below is a quotation from the tailor:

"As I said, by the deadlines, you have to make sure if it is urgent or not; if it is not, then we will finish it later. For schedule issues, we sometimes have trouble following the existing timelines because of human resources problems. The majority here are new employees, so they still need to learn. However, some of them went to different workplaces when after they have learned well. Task distribution is also an issue, sometimes. Some of the workers cannot do patterns; some cannot do the cutting. We have not found a solution to fulfill the orders in time and receive more orders. " $(P 4$, line 129-140).

The condition is not ideal based on previous studies. According to (Siagian, 2014), the determining factor to increase productivity is making continuous improvements. Osada (2014) states that excellent productivity and quality are the fruits of those who care about their work and try to make it better with 5S (Seiri, Seiton, Seiso, Seiketsu, and Shitsuke). Takashi Osada, in his book, explains the 5S: Seiri is to select and sort unused items; Seiton is to organize the workplace properly and arrange items well to make them easy to find; Seiso is maintaining the cleanliness of the workplace; Seiketsu is maintaining seiri, seiton, seiso to run continuously, and Shitsuke is a discipline in obeying the rules to shape the habits. Widianti (2015) explained that the goal of 5S is to keep the work environment safe, clean, comfortable, and favorable. This $5 \mathrm{~S}$ also has a positive relationship with quality and productivity.

Tailors always try to complete orders on time, but the work process is often too close to the promised day, as summarized from the interview:

"We always try to complete it on time, even though there are many unpredictable problems at home or workplace. There are a lot of urgent matters too. That is why we always make sure whether the 
order is urgent or not, we often work beyond the office hours. The orders have to be finished on time no matter what, even by taking an all-nighter or asking for help." (P6, row pages 75-80).

"Ideally, the order needs to be finished four to seven days before the deadlines, but in reality, it usually takes about two or one days before the deadline." (P4, line 185-186).

Tailors also try to provide information regarding the sewing process to their customers, but this is not consistently done to every customer. As seen in the interview quotation below:

"Usually as requested, but sometimes it is our initiative instead of their request. Usually, I send them photos as progress update, but sometimes I do not have time to do so when it is hectic. It is not the SOP, though." (P1, line 159-163).

"If the customer has many orders, we usually communicate the order's progress and make sure every detail is correct; if it is, then we proceed to cut. We are concerned because it is fatal. If it is a personal order, then we inform them when it is finished. If they asked, then we will tell them the current progress. "(P6, line 57-61).

This condition does not meet the ideal service quality criteria based on a previous study. According to Tjiptono (2016), service quality criteria include punctuality and customer comfort regarding information availability. Customer dissatisfaction is caused by the tailor's ineffectiveness in the sewing process, starting from material arrangements, documentation to ineffective communication.

This complex problem must be perceived from both sides to figure out the solutions in every stage: patterns, cutting, sewing, and fitting. Current problems might occur because of a missing process that caused the next stage to be hampered, so the order completion took longer than it should. The first step to see the cause of this problem is by identifying the problem from both customers and tailors from the eight stages of services and the possible impacts that might occur. Problem identification based on the stages of sewing services and their impact can be seen in Table 9.

Based on Table 9, that some missing details in the sewing stage process causing delays, discrepancies, data loss, and difficulty managing the order's schedule. It can be concluded that the delays are caused by ineffective execution in many stages resulting in customer's concern such as lateness, tailor's forgetfulness, no update information, and fear of the order completion is not as requested. What is expected from the customers is that the order is finished on time and as requested. Even though the tailors always try to fulfill the order fit with the customer's request, it is not adequately accommodated, disorganized and undisciplined, causing the lack of commitment to the customers. Identification of sewing service issues and expected services from customers and tailors can be seen in Table 9. 
Table 9. Identification of Sewing Service Issues and Expectations

\begin{tabular}{|c|c|c|c|c|c|c|c|c|}
\hline \multicolumn{9}{|c|}{ Identification of Sewing Service Issues and Expectations } \\
\hline & $\begin{array}{c}1 . \\
\text { Fabric Delivery }\end{array}$ & $\begin{array}{c}2 . \\
\text { Design }\end{array}$ & $\begin{array}{c}3 . \\
\text { Measurement }\end{array}$ & $\begin{array}{l}4 . \\
\text { Pattern \& Cutting }\end{array}$ & $\begin{array}{c}5 . \\
\text { Sewing }\end{array}$ & $\begin{array}{c}6 . \\
\text { Fitting }\end{array}$ & $\begin{array}{c}7 . \\
\text { Adjustment }\end{array}$ & $\begin{array}{c}8 . \\
\text { Clothing Delivery }\end{array}$ \\
\hline $\begin{array}{l}\text { Costumer's } \\
\text { Problems }\end{array}$ & $\begin{array}{l}\text { (not in research } \\
\text { focus range) }\end{array}$ & $\begin{array}{l}\text { They do not know } \\
\text { how to complete } \\
\text { information that had } \\
\text { to complete regarding } \\
\text { the details of the order } \\
\text { (Example: only } \\
\text { sending photos). }\end{array}$ & $\begin{array}{l}\text { They were } \\
\text { following the } \\
\text { tailor's instruction } \\
\text { without any request } \\
\text { as needed } \\
\text { (Example: body fit } \\
\text { or looser). }\end{array}$ & $\begin{array}{l}\text { They were } \\
\text { disappointed when } \\
\text { order results do not } \\
\text { meet expectation; } \\
\text { the tailor has no } \\
\text { updated information } \\
\text { and makes his own } \\
\text { decision. }\end{array}$ & $\begin{array}{l}\text { They do not } \\
\text { receive updated } \\
\text { information from } \\
\text { the tailors. }\end{array}$ & $\begin{array}{l}\text { They received } \\
\text { information } \\
\text { close to the } \\
\text { promised-day. }\end{array}$ & $\begin{array}{l}\text { They did repeat } \\
\text { adjustment. }\end{array}$ & $\begin{array}{l}\text { (not in research } \\
\text { focus range) }\end{array}$ \\
\hline $\begin{array}{l}\text { Impacts to } \\
\text { Costumer }\end{array}$ & $\begin{array}{l}\text { (not in research } \\
\text { focus range) }\end{array}$ & $\begin{array}{l}\text { Fashion design does } \\
\text { not meet the } \\
\text { expectation }\end{array}$ & $\begin{array}{l}\text { Clothing size } \\
\text { frequently not fit } \\
\text { properly }\end{array}$ & $\begin{array}{l}\text { The customer is not } \\
\text { satisfied; will not } \\
\text { repurchase the order }\end{array}$ & $\begin{array}{l}\text { Active customers } \\
\text { continue to } \\
\text { remind tailors }\end{array}$ & $\begin{array}{l}\text { Probably not } \\
\text { fitting }\end{array}$ & $\begin{array}{l}\text { Waiting for a } \\
\text { long time and } \\
\text { cloth can not be } \\
\text { used on special } \\
\text { event }\end{array}$ & $\begin{array}{l}\text { (not in research } \\
\text { focus range) }\end{array}$ \\
\hline $\begin{array}{l}\text { Customer } \\
\text { Expectation }\end{array}$ & $\begin{array}{l}\text { (not in research } \\
\text { focus range) }\end{array}$ & $\begin{array}{l}\text { The tailor understands } \\
\text { the design that the } \\
\text { customer will order, } \\
\text { giving some advice if } \\
\text { needed. }\end{array}$ & $\begin{array}{l}\text { The tailor gives } \\
\text { suggestions about } \\
\text { proper size to } \\
\text { customers. The } \\
\text { tailor takes notes } \\
\text { neatly in a book or } \\
\text { soft file. }\end{array}$ & $\begin{array}{l}\text { The tailor confirms } \\
\text { the order to } \\
\text { progress, re- } \\
\text { confirms the design } \\
\text { and size to reduce } \\
\text { errors. }\end{array}$ & $\begin{array}{l}\text { The tailor } \\
\text { finishing the order } \\
\text { on time, and the } \\
\text { result is matching } \\
\text { with the } \\
\text { expectations. }\end{array}$ & $\begin{array}{l}\text { Tailors provide } \\
\text { fitting time not } \\
\text { too close to the } \\
\text { promised-day. }\end{array}$ & $\begin{array}{l}\text { The tailor does } \\
\text { revisions and } \\
\text { done quickly. }\end{array}$ & $\begin{array}{l}\text { (not in research } \\
\text { focus range) }\end{array}$ \\
\hline $\begin{array}{l}\text { Tailor's } \\
\text { Problem }\end{array}$ & $\begin{array}{l}\text { (not in research } \\
\text { focus range) }\end{array}$ & $\begin{array}{l}\text { Tailors do not } \\
\text { understand the } \\
\text { fashion design of } \\
\text { customers because } \\
\text { lacking information. }\end{array}$ & Untidy recording. & $\begin{array}{l}\text { Having the } \\
\text { obstacles to } \\
\text { reconfirm because it } \\
\text { is busy. }\end{array}$ & $\begin{array}{l}\text { Having the } \\
\text { obstacles in time } \\
\text { management and } \\
\text { division of } \\
\text { workload. }\end{array}$ & $\begin{array}{l}\text { The time } \\
\text { allocation for } \\
\text { fitting is not yet } \\
\text { ideal in general. } \\
\text { Customers do } \\
\text { not come as } \\
\text { promised. }\end{array}$ & $\begin{array}{l}\text { Customers are } \\
\text { frequently } \\
\text { asking for many } \\
\text { revisions. }\end{array}$ & $\begin{array}{l}\text { (not in research } \\
\text { focus range) }\end{array}$ \\
\hline $\begin{array}{l}\text { Impacts to } \\
\text { Tailor }\end{array}$ & $\begin{array}{l}\text { (not in research } \\
\text { focus range) }\end{array}$ & $\begin{array}{l}\text { Fashion design does } \\
\text { not meet the } \\
\text { expectation. }\end{array}$ & $\begin{array}{l}\text { Time-consuming to } \\
\text { search note; When } \\
\text { the notes are lost, } \\
\text { the customer must } \\
\text { come back. }\end{array}$ & $\begin{array}{l}\text { If some part goes } \\
\text { wrong, it will } \\
\text { influence the total } \\
\text { time needed to } \\
\text { finish the order. }\end{array}$ & $\begin{array}{l}\text { Tailors are unable } \\
\text { to provide } \\
\text { updated } \\
\text { information. }\end{array}$ & $\begin{array}{l}\text { Lacking time } \\
\text { for adjustments } \\
\text { and clothing } \\
\text { will pile up in } \\
\text { the workshop. }\end{array}$ & $\begin{array}{l}\text { Processing the } \\
\text { revision in a } \\
\text { hurry. }\end{array}$ & $\begin{array}{l}\text { (not in research } \\
\text { focus range) }\end{array}$ \\
\hline
\end{tabular}




\begin{tabular}{|l|l|l|l|l|l|l|}
\hline \multicolumn{9}{|c|}{ Identification of Sewing Service Issues and Expectations } \\
\hline $\begin{array}{l}\text { Tailor } \\
\text { Expectation }\end{array}$ & $\begin{array}{l}\text { (not in research } \\
\text { focus range) }\end{array}$ & $\begin{array}{l}\text { The customer } \\
\text { provides a clear } \\
\text { explanation with } \\
\text { examples in the form } \\
\text { of pictures or sample } \\
\text { cloth or discusses } \\
\text { with the tailors. }\end{array}$ & $\begin{array}{l}\text { The customer } \\
\text { confirms each other } \\
\text { with the tailor about } \\
\text { which size is } \\
\text { comfortable for her. }\end{array}$ & $\begin{array}{l}\text { The tailor hope that } \\
\text { customers do not } \\
\text { ask for additional } \\
\text { design after the first } \\
\text { agreement. }\end{array}$ & $\begin{array}{l}\text { Capable to fast } \\
\text { respond when } \\
\text { there is an } \\
\text { information } \\
\text { request from the } \\
\text { customer. }\end{array}$ & $\begin{array}{l}\text { The customer } \\
\text { gives time } \\
\text { certainty for } \\
\text { clothing fitting } \\
\text { needs. }\end{array}$ \\
\hline
\end{tabular}




\section{Value Proposition Design}

Interaction between consumers and tailors is a matter to be considered. The details need to be informed and communicated in decision-making. Customers often send many "annoying" messages, then the tailors avoid them and focus on their work. This condition triggers the customer's concern because they expect updates about their order. It is a priority to improve sewing's service quality in solving the need for effective and efficient communication of both parties. Based on the findings of this research, a valuable solution for both parties is proposed. This value explains the benefits that consumers and tailors can expect from products and services. It is illustrated by value proposition design (Osterwalder et al., 2014), as shown in Figure 3.

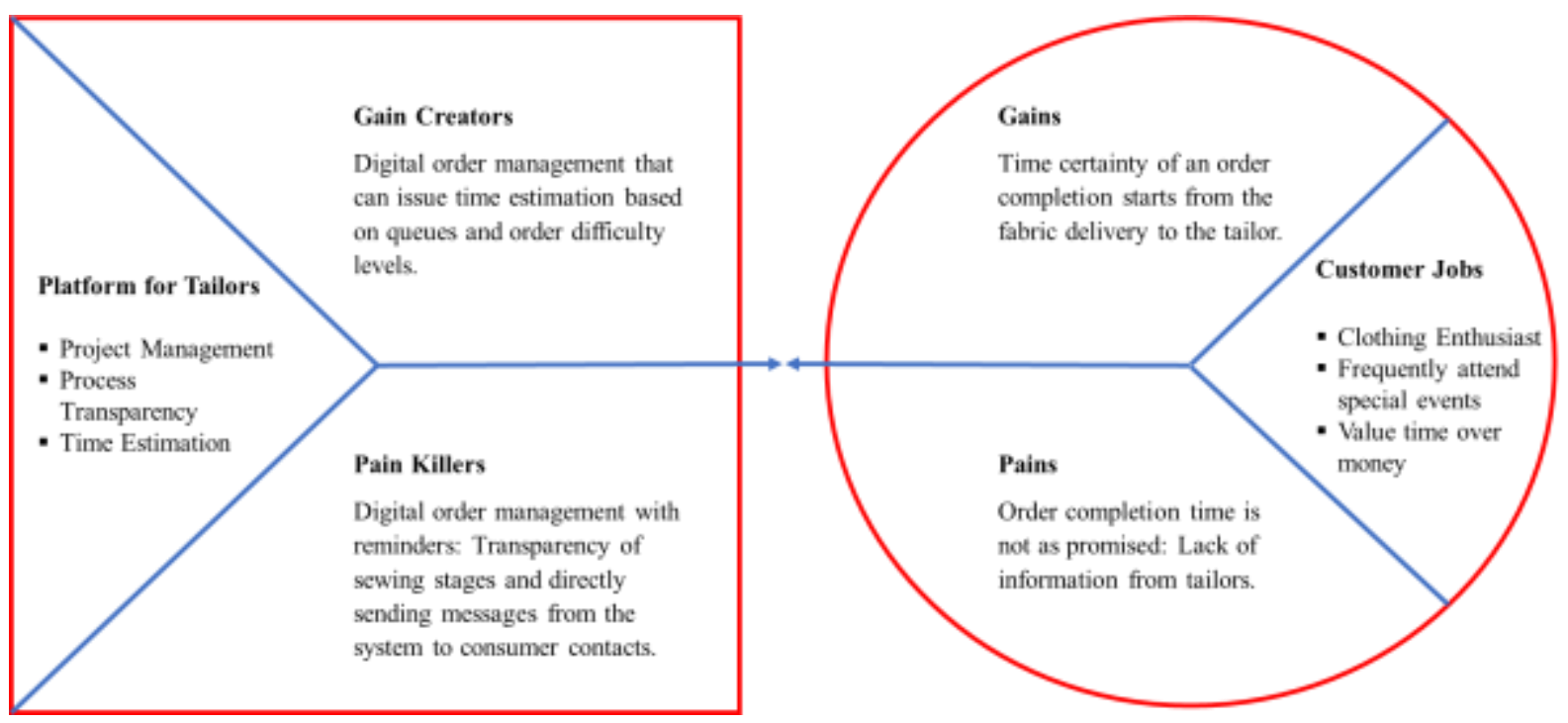

Figure 3. Value Proposition Design of Sewing Services

The value offered from the proposed formulation of the sewing services concept is based on existing problems between customers and tailors' lateness and lack of communication between the two parties. It creates concerns in using the sewing services. Value propositions offered on sewing services are:

a. It is digitizing the sewing business process with the proposed idea of a feature that will solve the problems experienced by consumers and tailors. Based on the findings, the issue is lateness and unclear information. The aim of this digital-based service is that the sewing services can run effectively and efficiently, so there will be a certainty in completing customer's orders.

b. It has a reminder system that is useful for tailors in completing orders.

c. It has the transparency in the sewing process that consumers can see to provide customers with regular updates.

Digitizing the business process will ease the tailors in data recording, managing schedule, task distribution, and predicting schedule if there is an order coming up. The reminder system is beneficial for finishing the order on time, and it will create a new discipline habit to work timely. According to Slamet et al. (2016), digital technology's adoption is proven to improve startups' performance, especially in increasing access to new domestic customers and sales.

Many complaints from customers due to lateness issue, customers keep asking the tailors regarding their order. Some tailors were able to respond quickly, but some were very slow and even try to avoid it, which concerns the customers. The proposed value is transparency in the sewing service process to provide information and 
communication as a form of new communication style involving higher consumers in the sewing service process. Engagement is an interaction between two parties to agree with each other so that no party is at a loss.

\section{B. Ideation Stage}

This stage is to generate, develop, and test ideas that can lead to solutions (Brown \& Wyatt, 2010). To generate ideas, we start with solving the problem by understanding insights and questions of How Might We (HMW). Then, the Questions of HMW serves as an opening for a Brainstorming session to generate ideas for the solution and be developed next. After that, we proceed to determine the ideas for the solution.

\section{How Might We}

After figuring out the issues between tailors and customers in the Inspiration Phase, the next step is to create a question to be solved. Table 10 below is the list of insights and 'how might we' questions.

Table 10. Questions’ How Might We’ (HMW)

\begin{tabular}{|c|c|c|}
\hline & INSIGHTS & $\begin{array}{l}\text { 'HOW MIGHT WE' } \\
\text { QUESTIONS }\end{array}$ \\
\hline a) & $\begin{array}{l}\text { Customers are worried because the tailor did not provide time and price } \\
\text { estimation since the tailors are unsure which order must be completed first. }\end{array}$ & $\begin{array}{l}\text { a) How can we } \\
\text { ensure a timely }\end{array}$ \\
\hline b) & $\begin{array}{l}\text { At the time of the sewing process, consumers waited and worried about no } \\
\text { update information from the tailor; they fear of the order was not completed } \\
\text { on time or the order did not meet expectations. }\end{array}$ & $\begin{array}{l}\text { order? } \\
\text { b) How can we } \\
\text { reduce customer's }\end{array}$ \\
\hline c) & $\begin{array}{l}\text { Customers regularly ask for updated information from the tailors; some tailors } \\
\text { respond quickly, and the others respond slowly or even too close to the } \\
\text { promised-day. }\end{array}$ & concerns? \\
\hline d) & $\begin{array}{l}\text { Few tailors responded to the customers because the tailors are busy finishing } \\
\text { their sewing orders. }\end{array}$ & \\
\hline e) & $\begin{array}{l}\text { Tailors are trying to complete as requested by customers. However, some of } \\
\text { them have not completed on time because they are currently understaffed, } \\
\text { poor time management, disorganized \& scattered data that cause their work to } \\
\text { be ineffective and inefficient. }\end{array}$ & \\
\hline
\end{tabular}

The result raises two questions, which drive us to create innovative solutions for tailors and customers' issues by asking the first question, "How might we ensure timely clothing order?" This question is driven by customers' insight into where they feel the order's completion is often late. The second question is "How might we reduce customer's concern?" customers are concerned because of the timing inaccuracy, lack of updates regarding their order, and fear of not getting the result as requested.

There are two main issues found from tailors and customers. The first issue is about time, and the second issue is about information and communication. Time issue lies in the lateness of completion time, in which the order is not finished as promised time. Moreover, tailors are overwhelmed with so many orders where the orders are not effectively and efficiently accommodated since the data record is still performed manually.

The second issue, information, and communication lie in the interaction between customers and tailors. Customers are concerned because they do not receive any information updates about their order, and few tailors respond quickly, so sometimes customers aggressively contact the tailors. This situation causes the level of trust between the two parties reduced and becomes a problem that has not been solved.

The proposed idea is to create a Tailor's Project Management Application that emphasizes the tailor's sewing process's timeliness to be more effective and efficient. Furthermore, the application will also solve information and communication issues between tailors and customers. The proposed features provide transparency in every stage of the sewing process, starting from receiving fabric, communicating design, pattern and fabric cutting, sewing process, finishing, fitting, adjustment, clothing delivery. This application is expected to provide accurate 
information about the tailor's current progress in completing the order to minimize the customer's concern or distrust to increase its credibility and timeliness.

\section{Brainstorming}

Brainstorming is performed with visual storytelling by describing a proposed product or service (Ideo.org, 2015). Brainstorming is performed by a team of two, where each member proposes ideas from the same questions, and the maximum time for explaining the idea is 5 minutes. There are ten ideas to ensure timely order and 14 ideas to reduce customer's concerns regarding order progress information.

\section{Determine}

The brainstorming stage produced a total of 24 general ideas. The team then determines the appropriate ideas for problem-solving and develops them into the application's digital features. Sixteen groups of ideas will be developed into app features. Based on the application's 16 features, all features are entirely accessible to tailors, but customers can access only ten features. The development of 16 application features can be seen in Table 11 .

Table 11. Ideas Development

\begin{tabular}{|c|c|c|c|c|c|}
\hline NO & CHOSEN IDEAS & FEATURES & $\mathrm{NO}$ & CHOSEN IDEAS & FEATURES \\
\hline 1 & $\begin{array}{l}\text { It needs a database } \\
\text { about customer profiles } \\
\text { and body sizes. }\end{array}$ & $\begin{array}{l}\text { Customer } \\
\text { Profile }\end{array}$ & 9 & $\begin{array}{l}\text { Automated time limit system } \\
\text { and a total of work time is not } \\
\text { changed. }\end{array}$ & $\begin{array}{l}\text { Time } \\
\text { Adjustment }\end{array}$ \\
\hline 2 & $\begin{array}{l}\text { An option where the } \\
\text { customers can meet the } \\
\text { tailors directly. }\end{array}$ & $\begin{array}{l}\text { Direct } \\
\text { Contact }\end{array}$ & 10 & $\begin{array}{l}\text { Automatic send progress } \\
\text { feature where the progress } \\
\text { update will be automatically } \\
\text { sent to customer's email. } \\
\text { - It can send direct progress } \\
\text { information to customer's } \\
\text { contacts. }\end{array}$ & $\begin{array}{l}\text { Direct } \\
\text { Information }\end{array}$ \\
\hline 3 & $\begin{array}{l}\text { Calendar for all orders } \\
\text { (Gantt Chart). }\end{array}$ & $\begin{array}{l}\text { Calendar } \\
\text { (Gantt Chart) }\end{array}$ & 11 & Status update to customers & History \\
\hline 4 & $\begin{array}{l}\text { Sewing theories pop up } \\
\text { messages. }\end{array}$ & $\begin{array}{l}\text { Pop up } \\
\text { Information }\end{array}$ & 12 & Confirmation before cutting. & Confirmation \\
\hline 5 & $\begin{array}{l}\text { Software that shows } \\
\text { every part of the sewing } \\
\text { process' feature. }\end{array}$ & $\begin{array}{l}\text { Timeline } \\
\text { Process }\end{array}$ & 13 & $\begin{array}{l}\text { The automated time limit that } \\
\text { has been agreed upon between } \\
\text { tailors and customers in } \\
\text { starting the work process to } \\
\text { certain stages. }\end{array}$ & Auto Cancel \\
\hline 6 & $\begin{array}{l}\text { The feature that can } \\
\text { automatically calculate } \\
\text { the length of work time } \\
\text { based on order queues. }\end{array}$ & $\begin{array}{l}\text { Total } \\
\text { Timeline } \\
\text { Process }\end{array}$ & 14 & $\begin{array}{l}\text { The incentive for tailors if they } \\
\text { were able to complete the } \\
\text { order before the due date. }\end{array}$ & Reward \\
\hline
\end{tabular}




\begin{tabular}{llllll}
\hline 7 & $\begin{array}{l}\text { A feature that can assist } \\
\text { to prioritize based on } \\
\text { the clothes' purpose. }\end{array}$ & $\begin{array}{l}\text { Time } \\
\text { Priority }\end{array}$ & 15 & $\begin{array}{l}\text { Penalty for tailors if they could } \\
\text { not finish the order as } \\
\text { promised time, such as fee } \\
\text { reduction, etc. }\end{array}$ & Punishment \\
\hline 8 & $\begin{array}{l}\text { A reminder system in } \\
\text { fulfilling orders. }\end{array}$ & $\begin{array}{l}\text { Call } \\
\text { Reminder }\end{array}$ & 16 & $\begin{array}{l}\text { Complete information } \\
\text { regarding tailors and } \\
\text { consumers. }\end{array}$ & Reviews \\
\hline
\end{tabular}

\section{Idea's Confirmation}

The proposed features are confirmed to the experts to figure out how important the feature is to be developed. Experts called in this study are from tailors and customers. Without proper communication and understanding between developers and users, it is impossible to create useful applications (Lowdermilk, 2013). Therefore, confirmation to the experts must be done to ensure the features are truly needed. There are levels of innovation in each feature (Vianna et al., 2011), namely:

(E) Essentials: Functions that are considered essential and needed;

(D) Desirable: Desire expressed by the users;

(O) Out of The Box: Things that are beyond the user's expectation and have the potential to create an impact.

Based on the expert's confirmation result, most of the proposed features are considered essential and needed. The experts' confirmation result regarding all proposed features that are considered as (E) Essentials are as follows:

a. Tailor's Features:

8 out of 16 features are considered necessary by $100 \%$ of experts

4 of 16 features are considered necessary by $75 \%$ of experts

4 of 16 features are considered necessary by $50 \%$ of experts

All features are confirmed to be necessary by at least $50 \%$ of experts

b. Customer's Features:

3 out of 10 features are considered necessary by $100 \%$ of experts

3 out of 10 features are considered necessary by $80 \%$ of experts

1 out of 10 features are considered necessary by $60 \%$ of experts

2 out of 10 features are considered necessary by $40 \%$ of experts

1 out of 10 features are considered necessary by $20 \%$ of experts

There are seven features confirmed as necessary by at least $50 \%$ of experts, and three features confirmed as necessary by less than $50 \%$ of experts.

\section{CONCLUSION}

This study aims to determine customers' significant issues who use custom clothing services, the tailors' significant issues, and solutions to these problems. The final result of the solution concept's formulation is in the form of digital application features. The customers' first issue is information and communication in the service stage, which drives customers' concern with tailors who do not respond quickly and responsively.

Second, a tailors' significant issue in serving their customers is the large number of orders causing the lack of information updates. This situation happened because the recording process is conducted manually (hand-written), and the sewing processes are poorly managed. Therefore, each stage service becomes ineffective and inefficient, which results in customers' complaints of lateness.

Third, the proposed solution's concept is emphasized on features that help tailors in managing their paperwork and schedules. The proposed features provide transparency in every stage process to facilitate information updates and reduce customer concern. Interaction in each stage of the service is equipped and supported with both parties' confirmation to prevent loss. The limitation of this research is up to the ideation stage; the concept's formulation 
of features from the findings of this research can be used as a standard for prototypes in the custom clothing field's startup business.

This research contributes in both academic and practical aspects. Academically, this research presents the stage to validate a digital-based idea as a custom clothing business solution. Besides, this research also presents interview protocols that can be used as a guide in exploring user personas. Practically, this research produces feature ideas that can be further developed to create a tailor's project management prototype. Findings from this study are expected to help small businesses in custom clothing in creating an effective sewing business process and increasing their competitiveness.

\section{REFERENCES}

Antonopoulou, K., \& Begkos, C. (2020). Strategizing for digital innovations: Value propositions for transcending market boundaries. Technological Forecasting and Social Change, 156. https://doi.org/10.1016/j.techfore.2020.120042

Anggono, Z. T. (2018, April 16). Number of start-ups projected to grow 20-30 percent this year, Bekraf says. The Jakarta Post. https://www.thejakartapost.com/news/2019/04/16/number-of-start-ups-projected-to-grow20-30-percent-this-year-bekraf-says.html

Äyväri, A., \& Jyrämä, A. (2017). Rethinking value proposition tools for living labs. Journal of Service Theory and Practice, 27(5), 1024-1039. https://doi.org/10.1108/JSTP-09-2015-0205

BEKRAF. (2020). Fashion. https://www.bekraf.go.id/subsektor/page/fashion

Brem, A., Bilgram, V., \& Marchuk, A. (2019). How crowdfunding platforms change the nature of user innovation - from problem-solving to entrepreneurship. Technological Forecasting and Social Change, 144, 348-360. https://doi.org/10.1016/j.techfore.2017.11.020

Brown, T. (2008). Design thinking. Harvard Business Review, 85-92.

Brown, T. (2009). Change by design: How design thinking transforms organizations and inspires innovation. Harper Collins.

Brown, T., \& Wyatt, J. (2010). Design thinking for social innovation IDEO. Development Outreach, 12(1), 2931.

Cahyadi, A., \& Prananto, A. (2015). Reflecting design thinking: a case study of the process of designing dashboards. Journal of Systems and Information Technology. https://doi.org/http://dx.doi.org/10.1108/JSIT-03-2015-0018.

Carlgren, L., Elmquist, M., \& Rauth, I. (2014). Design thinking: Exploring values and effects from an innovation capability perspective. The Design Journal, 17(3), 403-423. https://doi.org/doi: $10.2752 / 175630614 \times 13982745783000$

Carlgren, L., Rauth, I., \& Elmquist, M. (2016). Framing design thinking: The concept in idea and enactment. Creativity and Innovation Management, 25(1), 38-57. https://doi.org/https://doi.org/10.1111/caim.12153

Cassim, F. (2013). Hands on, hearts on, minds on: Design thinking within an educational context. International Journal of Art \& Design Education, 32(2), 190-202. https://doi.org/190-202. https://doi.org/10.1111/j.1476-8070.2013.01752.x

Chou, D. C. (2018). Applying design thinking method to social entrepreneurship. Computer, 55, 73-79. https://doi.org/www.sciencedirect.com/science/article/pii/S0920548917300387

Collins, H. (2013). Can design thinking still add value? Design Management Review, 24(2), 35-39. https://doi.org/10.1111/drev.10239

Cooper, A., Reimann, R., \& Cronin, D. (2007). About face 3: The essentials of interaction design. Wiley.

Cooper, R., Junginger, S., \& Lockwood, T. (2010). Design thinking and design management: A research and practice perspective. Allworth Press.

Creswell, J. W., \& Creswell, J. D. (2018). Research design qualitative, quantitative, and mixed methods approaches. SAGE Publications, Inc. 
Cruickshank, L., \& Evans, M. (2012). Designing creative frameworks: Design thinking as an engine for new facilitation approaches. International Journal of Arts and Technology, 5(1), 73-85. https://doi.org/10.1504/IJART.2012.044337

Dunne, D., \& Martin, R. (2006). Design thinking and how it will change management education: An interview and discussion. Academy of Management Learning \& Education, 5(4), 512-523. https://doi.org/http://citeseerx.ist.psu.edu/viewdoc/download?doi=10.1.1.193.9908\&rep=rep1\&type=pdf

Fink, A. (2003). The Survey Handbook. Sage Publications, Inc.

Ferreira, B., Silva, W., Oliveira, E., \& Conte, T. (2015). Designing personas with empathy map. Proceedings of the International Conference on Software Engineering and Knowledge Engineering, SEKE, 2015-January, 501-505. https://doi.org/10.18293/SEKE2015-152

Gates, M. (2015). Human-centered design. In J. Frenk \& S. J. Hoffman (Eds.), To save humanity: What matters most for a healthy future. Oxford University Press.

Glen, R., Suciu, C., Baughn, C. C., \& Anson, R. (2015). Teaching design thinking in business schools. International Journal of Management $182-192$. https://doi.org/10.1016/j.ijme.2015.05.001

Googletrends. (2020). No Title. https://trends.google.co.id/trends/explore?date=today 5-y\&geo=ID\&q=pakaian custom

Gruber, M., de Leon, N., George, G., \& Thompson, P. (2015). Managing by design. Academy of Management Journal, 58(1), 1-7. https://doi.org/doi: 10.5465/amj.2015.4001

Holloway, M. (2009). How tangible is your strategy? How design thinking can turn your strategy into reality. Journal of Business Strategy, 30(2/3), 50-56. https://doi.org/doi: 10.1108/02756660910942463

Howard, Z. (2012). From concept to capability: Developing design thinking within a professional services firm. In Durling, D, Israsena, P, \& Tangsantikul, J (Eds.) Proceedings of the 2012 Design Research Society (DRS) Biennial International Conference, 2, 729-739. https://eprints.qut.edu.au/61082/

Huber, F. (2017). Entrepreneurial teams and design thinking: A longitudinal evaluation of success factors. [Dissertation] Edinburgh Napier University. https://www.napier.ac.uk/ /media/worktribe/output976980/entrepreneurial-teams-and-design-thinking-a-longitudinal-evaluation-of-success-factors.pdf

Ideo.org. (2015). The field guide to human-centered design. https://bestgraz.org/wpcontent/uploads/2015/09/Field-Guide-to-Human-Centered-Design_IDEOorg.pdf

IDEO. (2016). IDEO corporate website. https://www.ideo.com

Jatmiko, L. D. (2020). APJII: 196,7 juta warga Indonesia sudah melek internet. https://teknologi.bisnis.com/read/20201110/101/1315765/apjii-1967-juta-warga-indonesia-sudah-melekinternet

Kolko, J. (2015). Design thinking comes of age. Harvard Business Review, 93(9). https://doi.org/https://hbr.org/2015/09/design-thinking-comes-of-age

Kotler, P., \& Armstrong, G. (2016). Principles of marketing. Pearson.

Kristensen, H. S., \& Remmen, A. (2019). A framework for sustainable value propositions in product-service systems. Journal of Cleaner Production, 223, 25-35. https://doi.org/10.1016/j.jclepro.2019.03.074

Lanning, M. (2003). An introduction to the market-focused philosophy, framework and methodology called delivering profitable value. www.exubrio.com/services/\%0Awhite_papers/DPVIntro-eXubrio.pdfm\%0A

Liedtka, J., \& Ogilvie, T. (2011). Designing for growth: A design thinking tool kit for managers. Columbia University Press.

Liedtka, J. (2015). Perspective: Linking design thinking with innovation outcomes through cognitive bias reduction. Journal of Product Innovation Management, 32(6), 925-938. https://doi.org/doi: 10.1111/jpim. 12163

Lowdermilk, T. (2013). User-centered design. O’Reilly Media.

Martin, R. (2013). Introduction. In R. Martin \& K. Christensen (Eds.), Rotman on design. University of Toronto Press. 
Merdeka. (2019, October). Menkominfo: lebih banyak startup gagal dibanding berhasil di Indonesia. https://www.merdeka.com/uang/menkominfo-lebih-banyak-startup-gagal-dibanding-berhasil-diindonesia.html

MIKTI., T. $\quad$ I. (2018). Mapping \& database startup Indonesia. https://www.kemenparekraf.go.id/asset_admin/assets/uploads/media/pdf/media_1589838814_Mapping_ Database_Startup_Indonesia_2018.pdf

Mosely, G., Wright, N., \& Wrigley, C. (2018). Facilitating design thinking: A comparison of design expertise. Thinking Skills and Creativity, 27(January), 177-189. https://doi.org/10.1016/j.tsc.2018.02.004

Movanita, A. N. K. (2019, April). Banyak "startup" gagal berkembang, ini penyebabnya. https://www.google.com/amp/s/amp.kompas.com/money/read/2019/04/04/100900426/banyak-startupgagal-berkembang-ini-penyebabnya

Nakano, N., Oliveira, J. A. D. B. e., \& Jorente, M. J. V. (2018). Design thinking as a dynamic methodology for information science. Information and Learning Science, 119(12), 743-757. https://doi.org/10.1108/ILS07-2018-0061

Nielsen, S. L., \& Stovang, P. (2015). DesUni: university entrepreneurship education through. Education + Training, 57(8/9), 977-991. https://doi.org/http://dx.doi.org/10.1108/ET-09-2014-0121

Neuman, W. L. (2014). Social research methods. Pearson Education Limited.

Nooyi, I., \& Ignatius, A. (2015). How Indra Nooyi turned design thinking into strategy: An interview with PepsiCo's CEO. Harvard Business Review, 81-85. https://hbr.org/2015/09/how-indra-nooyi-turneddesign-thinking-into-strategy

Ojasalo, J., \& Ojasalo, K. (2018). Service logic business model canvas. Journal of Research in Marketing and Entrepreneurship, 20(1), 70-98. https://doi.org/10.1108/JRME-06-2016-0015

Osada, T. (2014). Sikap kerja 5S. Jakarta: PPM-Bisnis2030

Osterwalder, A., Pigneur, Y., Smith, A., Bernarda, G., \& Papadakos, P. (2014). Value proposition design. John Wiley \& Sons.

Payne, A., \& Frow, P. (2014). Developing superior value propositions: A strategic marketing imperative. Journal of Service Management, 25(2), 213-227. https://doi.org/10.1108/JOSM-01-2014-0036

Plattner, H., Meinel, C., \& Leifer, L. J. (2011). Design thinking: Understand - improve - apply. Springer.

Porcini, M. (2009). Your new design process is not enough - Hire design thinkers! Design Management Review, 20(3), 6-8. https://doi.org/https://doi.org/10.1111/j.1948-7169.2009.00017.x

Sándorová, Z., Repáňová, T., Palenčíková, Z., \& Beták, N. (2020). Design thinking - A revolutionary new approach in tourism education? Journal of Hospitality, Leisure, Sport and Tourism Education, 26. https://doi.org/10.1016/j.jhlste.2019.100238

Sandstrom, S., Edvardsson, B., Kristensson, P. and Magnusson, P. (2008). Value in use through service experience. Managing Service Quality, 18(2), 112-126.

Sato, S., Lucente, S., Meyer, D., \& Mrazek, D. (2010). Design thinking to make organization change and development more responsive. Design Management Review, 21(2), 44-52. https://doi.org/https://doi.org/10.1111/j.1948-7169.2010.00064.X

Siagian, S. P. (2014). Manajemen sumber daya manusia. Bumi Aksara.

Sekaran, U., \& Bougie, R. (2016). Research methods for business. John Wiley \& Sons Ltd.

Shamim, A., Ghazali, Z., \& Albinsson, P. A. (2017). Construction and validation of customer value co-creation attitude scale. Journal of Consumer Marketing, 34(7), 591-602. https://doi.org/10.1108/JCM-01-20161664

Slamet, R., Nainggolan, B., Roessobiyatno, Ramdani, H., Hendriyanto, A., \& Ilma, L. (2016). Strategi pengembangan UKM digital dalam menghadapi era pasar bebas. Jurnal Manajemen Indonesia, 16(2).

Tjiptono, F. (2016). Service quality and satisfaction. Andi.

Tonkinwise, C. (2011). A taste for practices: Unrepressing style in design thinking. Design Studies, 32(6), 533545. https://doi.org/doi: 10.1016/j.destud.2011.07.001 
Vianna, M., Vianna, Y., Adler, I. K., Lucena, B., \& Russo, B. (2011). Design thinking: Business innovation. MJV Press.

Wattanasupackoke, T. (2012). Design thinking, innovativeness and performance: An empirical examination. International Journal of Management and Innovation, 4(1).

Widianti, T. (2015). Implementasi 5S untuk optimalisasi keselamatan, kesehatan, dan performansi kerja. Jurnal Teknik Industri, 2(2), 114.

Yadika, B. (2019, October). Rudiantara: startup yang bisa sukses cuma 5 persen. https://m.liputan6.com/bisnis/read/4081420/rudiantara-startup-yang-bisa-sukses-cuma-5-persen

Yi, Y., Wang, Y., \& Shu, C. (2020). Business model innovations in China: A focus on value propositions. Business Horizons, 63(6), 787-799. https://doi.org/10.1016/j.bushor.2020.07.002

Yin, R. K. (2014). Case study research design and methods. Sage Publications, Inc. 